Maja Putica

OTP Banka ad Novi Sad maja.putica@otpbanka.rs

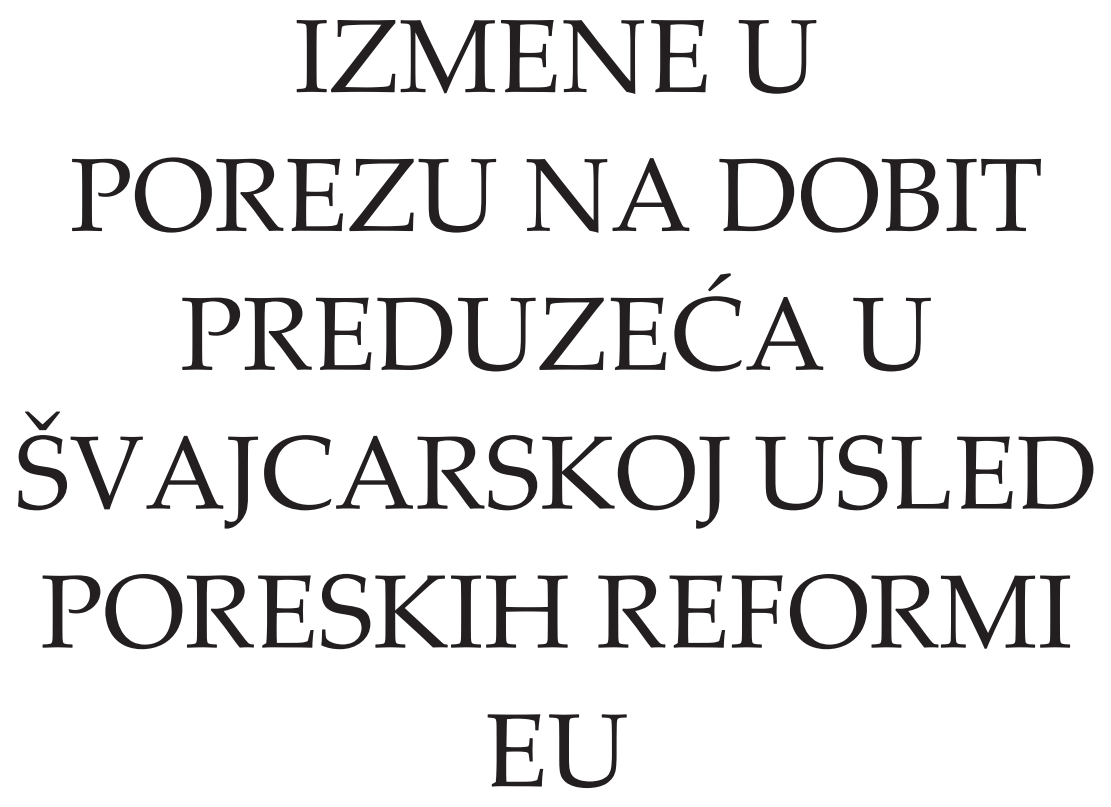

Prevod

obezbedio

autor

\title{
Rezime
}

Poreske reforme na dobit preduzeća su neminovna pojava u 21. veku kada je nepravična poreska konkurencija između zemalja uzela maha. Iako nije članica Evropske unije, Švajcarska je zahvaćena ovim merama, obzirom da je jedna od vodećih ekonomija u svetu koja najviše profitira od preferncijalnih poreskih režima. Za potrebe ovog istraživanja analizirane su aktuelne izmene poreskog tretmana dobiti preduzeća na sva tri nivoa vlasti u Švajcarskoj koje se dešavaju usled poreske reforme preduzeća. Rad ukazuje na osnovne karakteristike sistema oporezivanja dobiti u Švajcarskoj u cilju razumevanja promena koje slede i razloge opravdanosti tih promena sa aspekta Evropske unije i organizacije OECD. Shodno tome se predlaže nekoliko ključnih mera koje bi mogle da doprinesu implementaciji reformi - da kantoni prihvate međunarodna pravila ili da snize poreske stope na dobit preduzeća na nivo međunarodne konkurentnosti. Nivelisanje kantonalnih poreskih stopa je u toku, tako da se u narednom periodu očekuju glasanja na referendumu u cilju definisanja daljih koraka u prihvatanju poreskih pravila. U slučaju da poreska reforma III bude neuspešna, nove reforme će biti neizbežne.

Ključne reči: Švajcarska, porez na dobit preduzeća, poreske reforme, Evropska unija, izmene u porezu na dobit preduzeća, CTR III 


\section{CHANGES IN \\ CORPORATE PROFIT \\ TAX IN SWITZERLAND \\ DUE TO THE EU TAX \\ REFORM}

Maja Putica

OTP Bank ad Novi Sad maja.putica@otpbanka.rs

\author{
Translation \\ provided by \\ the author
}

\section{Summary}

Tax reforms concerning corporate profit are an inevitable phenomenon in the $21^{\text {st }}$ century with the unfair tax competition among countries going rampant. Although not a member of the European Union, Switzerland is affected by these measures, since it is one of the leading economies in the world which profits the most from preferential tax regimes. For the purposes of this study we analyzed the current changes in the tax treatment of corporate profit at all three levels of government in Switzerland which occur due to the Corporate Tax Reform. The paper points to the basic features of the system of corporate taxation in Switzerland in order to understand the changes that followed and the reasons justifying the change in terms of the European Union and the OECD. Accordingly, we propose several key measures that could contribute to the implementation of reforms - for the cantons to accept the international rules or to lower the tax rates on corporate profit to the level of international competitiveness. Aligning the cantonal tax rates has been underway, and in the forthcoming period a referendum is expected to take place with a view to defining further steps in accepting the tax rules. In case that the tax reform III fails, new reforms will be inevitable.

Keywords: Switzerland, corporate profit tax, tax reform, European Union, changes in corporate profit tax, CTR III

JEL: H25, H71 


\section{Uvod}

Svaka država nastoji da svoj poreski sistem učini što povoljnijim i na taj način privuče brojne mobilne faktore proizvodnje. Države koje posluju u skladu sa principom „no or low taxation" su naročitou centru pažnje. Jedna od tih država je i Švajcarska, koja je zbog atraktivnosti stopa poreza na dobit preduzeća, u 2013. godini proglašena za prvu državu sveta prema indeksu svetske konkurentnosti. Švajcarsku već decenijama odlikuju preferencijalni poreski režimi i diferenciran status inostranih preduzeća u odnosu na domaća preduzeća. Oporezivanje dobiti se vrši na tri nivoa vlasti u skladu sa federativnim uređenjem ove zemlje. Zbog takve strukture, svaki od 26 kantona ima svoj Ustav i poreski zakon na osnovu kog ima pravo da oporezuje dobit i kapital (dividende). Zajedno sa federativnim zakonom o direktnom federalnom porezu, postoji ukupno 27 različitih poreskih zakona koji direktno pogađaju prihode.

Usled aktuelnih poreskih reformi koje se sprovode pod okriljem organizacije OECD i Evropske unije u cilju suprotstavljanja štetnoj poreskoj konkurenciji, pred ovu državu se postavlja zadatak eliminisanja povlašćenih režima i usklađivanja poreskog sistema sa standardima što bi moglo da ugrozi njenu poziciju i status „poreskog raja“. Obzirom da je tek 2009. godine skinuta sa OECD-ove "sive liste“, i dalje se stiče utisak da Švajcarska nije toliko "otvorena“ i spremna da se potpuno uključi u borbu protiv međunarodne nepravične konkurencije. Ipak, pojedine promene u vidu snižavanja poreskih stopa od strane kantona su se već desile pa se aktivniji pristup i potpuna primena reforme očekuju do 2020. godine. Ukoliko Švajcarska ne postupi u skladu sa reformama koje vode ka nivelisanju poreskih stopa na međunarodnom nivou, to će dovesti do ogromnih troškova (izgubljenih prihoda) koje se procenjuju na bilione franaka, i koji su veći čak i od onih troškova koji bi nastali ukoliko se reforme sprovedu u ovoj zemlji.

\section{Atraktivnost poreskog režima Švajcarske - preferencijalno oporezivanje dobiti i diferenciran status preduzeća}

Švajcarska predstavlja federativno uređenu zemlju sastavljenu od jedinica - kantona (ukupno dvadeset šest) i opština. Shodno tome, i njen celokupan poreski sistem je zasnovan na federalnom sistemu. Oporezivanje u Švajcarskoj se vrši na sva tri nivoa vlasti i to (Radičić \& Raičević, 2008):

1. Nivo federacije;

2. Nivo država-članica federacije (nivo kantona);

3. Nivo lokalnih kolektiviteta (nivo opština).

Kada se govori o porezu na dobit preduzeća, isti je regulisan federalnim poreskim zakonom koji važi na nivou federacije (Federal Tax Law) i kantonalnim poreskim zakonima (Cantonal Tax Laws). Federativni porez je neodvojivi od kantonalnog, što znači da se prilikom obračuna poreza na dobit, na federativni porez dodaje i obračunava porez koji važi za određeni kanton u kome se nalazi preduzeće, odnosno u kome se ostvaruje dobit. Obzirom da se u složenoj državi oporezivanje vrši na različitim nivoima vlasti, poreski zakoni na nivou članica federacija moraju biti usaglašeni sa opštim principima navedenim u Federalnom poreskom zakonu. Opštine imaju određen stepen samostalnosti prilikom uvođenja svojih poreza ali u granicama koje je propisao kanton. Zato je poresko opterećenje u Švajcarskoj od kantona do kantona i od opštine do opštine različito.

U cilju privlačenja stranog kapitala i investicija, mnoge zemlje među kojima je i Švajcarska, teže formiranju preferencijalnih poreskih režima za pravna lica. Ono što čini ove režime posebnim jeste to što pravna lica $u$ okviru njih uživaju povlašćene uslove u smislu nižih poreskih stopa, jednostavnog procesa za osnivanje preduzeća, i ostali uslovi koji nisu zastupljeni u uobičajenim (tzv. „normalnim“) poreskim režimima. Preferencijalni poreski režimi iskristalisali su se vremenom kao posledica federativnog uređenja Švajcarske države. Režimi su konstruisani na kantonalnom nivou, čije će suzbijanje upravo biti glavna tema poreske reforme III. 


\section{Introduction}

Each country is trying to keep its tax system auspicious and thus attract many mobile factors of production. The states operating in accordance with the principle of "no or low taxation" are particularly in the center of observation. One such country is Switzerland, which was, due to the attractiveness of its corporate profit tax rate in 2013, ranked the first country in the world according to the global competitiveness index. For decades Switzerland has been characterized by preferential tax regimes and differentiated status of foreign corporations in relation to domestic corporations. Taxation of profit is made on the three levels of government in accordance with the federal arrangement of the country. Because of this structure, each of the twenty six cantons has its own constitution and tax law based on which it has the right to tax profits and equity (dividends). Together with the federal law on direct federal tax, there is a total of twenty seven different tax laws that directly affect income.

Due to the current tax reforms that are being implemented under the auspices of the OECD and the European Union with a view to countering harmful tax competition, this country was given the task of eliminating the preferential regimes and harmonizing the tax system with the standards that could endanger its position and the status of "tax haven". Considering that it was only in 2009 that Switzerland was taken from the OECD's "gray list", the impression remains that Switzerland is not as "open" and ready to fully engage in the fight against the unfair international competition. However, certain changes in the form of lowering tax rates by the cantons have already taken place, and a more active approach and full implementation of the reform is expected by 2020. If Switzerland does not comply with the reforms that lead to the leveling of the tax rates at the international level, it will undergo huge costs (lost revenue), which are estimated at billions of francs, thus being even higher than the costs that would be incurred if the reforms were implemented in this country.

\section{Attractiveness of the Tax Regime of Switzerland - Preferential Profit Taxation and Differentiated Corporate Status}

Switzerland is a federal country made up of units - cantons (twenty six) and municipalities. Accordingly, its entire tax system is based on the federal system. Taxation in Switzerland is done on all three levels of government, as follows (Radičić \& Raičević, 2008):

1. The level of the federation;

2. The level of the federation member states (cantonal level);

3. The level of local collectivities (municipal level).

The Corporate Profit Tax is regulated by the federal tax law applicable at the federal level (Federal Tax Law) and cantonal tax laws (Cantonal Tax Laws). The federal tax is inseparable from the cantonal, which means that when calculating the income tax, the federal tax is increased by the calculated specific cantonal tax valid in the canton in which the company is located, or in which the profit is realized. Given that in the unitary state, taxation is performed at different levels of government, tax laws in the member states must comply with the general principles set out in the Federal Tax Law. Municipalities have a degree of autonomy when introducing their taxes or within the limits prescribed by the canton. Therefore, the tax burden in Switzerland is different from canton to canton and from municipality to municipality.

In order to attract foreign capital and investment, many countries, including Switzerland, tend to form the preferential tax regimes for legal entities. What makes these arrangements special is that the legal entities within them enjoy favorable conditions in terms of lower tax rates, a simplified process for the establishment of corporations, and other conditions that are not present in the conventional (i.e. "regular") tax regime. Preferential tax regimes crystallized over time as a result of the federal constitution of the Swiss state. The regimes are designed at the cantonal level, and their suppression will be the main topic of the tax reform III.

In Switzerland, at the cantonal level, there are four main preferential regimes for (Deloitte, 2015): 
U Švajcarskoj, na kantonalnom nivou, postoje četiri glavna preferencijalna režima za (Deloitte, 2015):

1. Holding kompanije (Holding company);

2. Mešovite kompanije (Mixed company);

3. Matične kompanije (Principal company);

4. Finansijske kompanije/ogranci (Finance company).

Holding privilegije - Da bi neka holding kompanija imala status "čiste“ kompanije i ostvarila pravo na podsticaje u pogledu poreske obaveze, mora da ispunjava sledeće uslove (KPMG Switzerland, 2014):

- osnovna svrha poslovanja holding kompanije mora biti isključivo upravljanje dugoročnim investicijama u subsidijarnim preduzećima;

- kompanija ne sme da se bavi komercijalnom aktivnošću na teritoriji Švajcarske;

- $2 / 3$ ukupne aktive treba da čine investicije u supsidijarna preduzeća (akcije), odnosno 2/3 ukupnog bruto prihoda moraju činiti dividende po osnovu akcija.

Karakteristike i poreski tretman rezultata poslovanja formacije su:

- Aktivnost formacije - investiciona aktivnost bez učešća trećih strana.

- Poreska stopa na nivou federacije: korporacije, članice Holdinga se oporezuju samo na nivou federacije efektivnom poreskom stopom u iznosu od 7,83\% (nominalna 8,5\%).

- Poreska stopa na nivou kantona: na kantonalnomi opštinskom nivou oslobođene su plaćanja poreza na dobit (poreska stopa je $0,00 \%)$.

Mešovita preduzeća predstavljaju domaća preduzeća ili stalna predstavništva stranih kompanija koje imaju mogućnost obavljanja ograničene komercijalne aktivnosti na teritoriji Švajcarske (za razliku od Holdinga).

- Aktivnost formacije: Glavni uslov za sticanje statusa mešovitog preduzeća jeste realizacija minimum $80 \%$ prihoda od komercijalnih aktivnosti izvan Švajcarske, odnosno realizovanje maksimum $20 \%$ prihoda tih aktivnosti u Švajcarskoj. Mnogi kantoni postavljaju i uslov u pogledu troškova, tako da minimum $80 \%$ troškova mora biti povezan sa komercijalnim aktivnostima izvan Švajcarske.
Preferencijalni poreski tretman mešovita preduzeća ostvaruju upravo na inostrane prihode i to od strane kantona, ali ne $\mathrm{i}$ od federacije. U tom slučaju odvojeno se tretiraju prihodi ostvareni u Švajcarskoj u odnosu na ino prihode.

- Poreska stopa na nivou federacije: porez na prihode ostvarene izvan Švajcarske ove kompanije plaćaju po stopi u rasponu od $8,50 \%$. Porez na prihode ostvarene $u$ Švajcarskoj, ove kompanije plaćaju po redovnoj poreskoj stopi na dobit preduzeća.

- Poreska stopa na nivou kantona: $\mathrm{u}$ kantonima su niže stope poreza na dobit na inostrane prihode - od 8,5\% do 10,5\%).

Principalna (matična) preduzeća su multinacionalne korporacije, među kojima postoji glavno (matično) preduzeće locirano uŠvajcarskoj, u kome su skoncentrisane sve odgovornosti, rizici i centralizovani princip poslovanja. Ova formacija postoji isključivo na federativnom nivou zbog čega se ostvaruju uštede sa jedne strane kroz smanjenje operativnih troškova poslovanja, a sa druge strane kroz uštede u porezima.

- Aktivnost formacije: Komercijalne/ proizvodna delatnost se ostvaruje preko grupa kompanija (agenata, subsidijara).

- Poreska stopa na federativnom nivou iznosi $8,5 \%$.

- Efektivna poreska stopa na kantonalnom nivou za ovu vrstu poreskog režima uz uslov određenog broja zaposlenih radnika i ostvarenih $90 \%$ prihoda od prodaje proizvoda iznosi $5 \%-8 \%$.

Poreska osnovica za porez na dobit kod principalnih preduzeća u slučaju komercijalnih aktivnosti predstavlja minimum $50 \%$ profita dok u slučaju proizvodnih aktivnosti, minimum $65 \%$ profita ulazi u poresku osnovicu za oporezivanje.

Faktori koji su uticali na rasprostranjenje ovakvog poreskog režima su federativno uređenje Švajcarske, povoljna poslovnoprijateljska klima, nezavisnost od organa Evropske unije i Evropske monetarne unije, povoljni poreski režimi i ostalo (Kurtin, 2013).

Poslednja formacija koja uživa poreske povlastice jesu finansijske kompanije, odnosno ogranci inostranih finansijskih preduzeća.

Karakteristike i poreski tretman poslovnih rezultate formacije su: 
1. Holding companies;

2. Mixed companies;

3. Parent companies;

4. Finance companies/branches.

Holding privileges - To let a holding company have the status of a "clean" company, eligible for incentives in terms of tax liabilities, it must meet the following conditions (KPMG Switzerland, 2014):

- The core purpose of the holding company must be the long-term management of investments in subsidiary companies;

- The company must not engage in commercial activities on the territory of Switzerland;

- $2 / 3$ of the total assets should be invested in subsidiary companies (shares), or $2 / 3$ of the total gross income must consist of dividends on shares.

Characteristics and tax treatment of the business result of the formation are as follows:

- Activity of formation: Investment activity without the involvement of third parties.

- The tax rate at the federal level: Corporations, the holding members, are taxed only at the federal level with the effective tax rate in the amount of $7.83 \%$ (nominal $8.5 \%$ ).

- The tax rate at the cantonal level: At the cantonal and municipal level, the holding companies are exempt from income tax (tax rate is $0.00 \%$ ).

Mixed companies (joint venture) are local companies or permanent representative offices of foreign companies, which have limited ability to conduct commercial activities in the territory of Switzerland (unlike holding companies).

Characteristics and tax treatment of business result of the formation are:

- Activity of formation: The main condition for obtaining the status of a mixed company is the realization of a minimum of $80 \%$ of income from commercial activities outside Switzerland or the realization of a maximum of $20 \%$ of revenues based on these activities in Switzerland. Many cantons have set a condition in terms of cost, so that a minimum of $80 \%$ of costs should be associated with commercial activities outside Switzerland. The preferential tax treatment is achieved by mixed companies based on foreign income by the cantons, but not by the Federation. In this case the income realized in Switzerland and foreign incomes are treated separately.

- The tax rate at the federal level: The tax on revenues generated outside Switzerland is paid by the company at a rate of $8.50 \%$. The taxes on income generated in Switzerland are paid by the company at the regular tax rate on corporate profit.

- The tax rate at the cantonal level: The cantons apply lower income tax rates on foreign income - from $0.5 \%$ to $2.5 \%$ ).

Principal (parent) companies are multinational corporations, whose main (parent) company is located in Switzerland, where all responsibilities and risks are concentrated according to the centralized business principle. This formation exists solely on the federal level, which is why the savings are achieved on the one hand through the reduction of operating costs, and on the other hand, through savings in taxes.

Characteristics and tax treatment of business result of the formation are:

- Activity of formation: Commercial/ production activities are realized through a group of companies (agents, subsidiaries).

- The tax rate at the federal level is $8.5 \%$.

- The effective tax rate at the cantonal level for this type of tax regime, with the condition of a specific number of employees and generated $90 \%$ of revenue from product sales, is $0.5 \%-2.5 \%$.

The tax base for corporate profit tax on principal companies in the event of commercial activity represents at least $50 \%$ of profits whereas in the case of manufacturing activity, the minimum of $65 \%$ of profit serves as the tax base for taxation.

The factors affecting the distribution of this tax regime are the federalism of Switzerland, the favorable business-friendly climate, the independence of the bodies the European Union and the European Monetary Union, the favorable tax regimes, etc. (Kurtin, 2013).

The last formation that enjoys tax benefits are financial companies or branches of foreign financial companies.

Characteristics and tax treatment of the business result of the formation are:

- Activity of formation: Foreign companies through units located in Switzerland lending money to other foreign companies outside 
- Aktivnost formacije: inostrane kompanije Sjedinjenim Američkim Državama. posredstvomjedinicalociranih u Švajcarskoj daju pozajmice drugim stranim preduzećima izvan Švajcarske, investiraju dugoročno ili kratkoročno u oročene depozite i obavljaju ostale finansijske aktivnosti (Baumgartner \& Kunen, 2015).

- Poreska stopa na nivou federacije: efektivan porez na federativnom nivou iznosi $7,83 \%$, uz ostvarene olakšice po osnovu odbitka kamate na pozajmljeni kapital.

- Poreska stopa na kantonalnom nivou je $1 \%-2 \%$ uključujući umanjenja po osnovu odbitka

Grafik 1. Inovativni kapaciteti kompanija u svetu

\section{Inovativni kapaciteti kompanija}

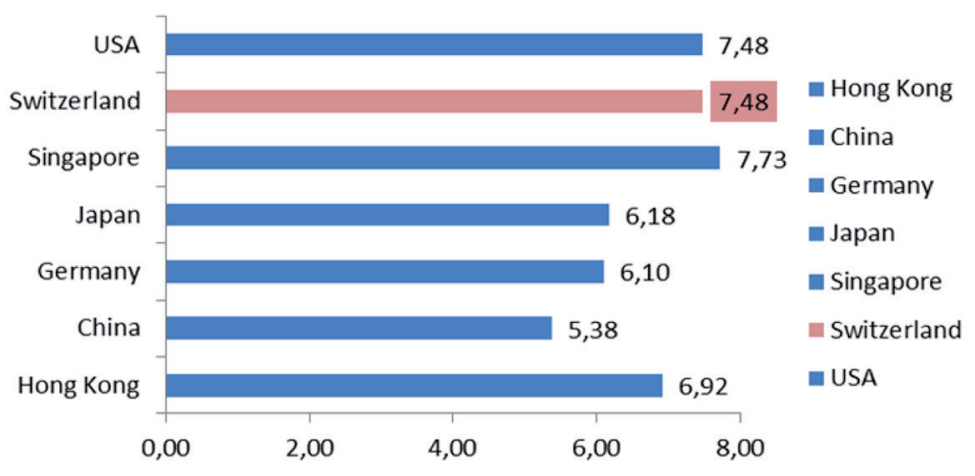

Izvor: Sajt KPMG Switzerland (https://home.kpmg.com/ch/en/home.html) Pristup 18.03.2017. kamate na pozajmljeni kapital.

Preferencijalni poreski režimi mogu od određenih zemalja da stvore "poreske rajeve“ i predstavljaju poreske podsticaje, odnosno režime u kojima se daje drugačiji tretman oporezivanja prihoda koji su ostvareni na domicilnoj teritoriji $u$ odnosu na prihode koji su ostvareni u inostranstvu („ring-fencing“). Uzimajući u obzir da je prosečna stopa poreza na dobit domicilnih peduzeća u 2015. godini iznosila $17.92 \%$, sva preduzeća koja uživaju povlašćen poreski status plaćaju niže iznose poreza od navedene. U sklopu poreske reforme koja se sprovodi u Švajcarskoj, intenzivno se radi na ukidanju preferencijalnih režima koje iznad nabrojane formacije preduzeća ostvaruju.

Kada se govori o off-shore finansijskim centrima, moglo bi se reći sa sigurnošću da Švajcarska sa svojim preferencijalnim poreskim režimima svakako ispunjava uslove koje je svrstavaju u off-shore centar. Ujedno, u cilju privlačenja stranog kapitala, ona nudi povoljnije poreske uslove za strana preduzeća i tako ih diferencira u odnosu na domaća preduzeća. Prema pojedinim autorima, svaka država koja menja svoje poreske zakone i preduzima druge mere da putem fiskalne politike privuče strani kapital, može se smatrati poreskim rajem (Todorović-Đurović \& Đorđevič, 2011). Upravo većina ekonomista smatra da je prvi pravi poreski raj upravo Švajcarska. Još 2015. godine Švajcarska je proglašena za najatrakivniju i najinovativniju zemlju sveta, $u$ rangu sa
Švajcarska nema zakon koji kontroliše strana preduzeća tako da profit koji ta preduzeća ostvare ne podleže obavezi plaćanja poreza (Bessard, 2008).

Komparacija izvršena na međunarodnom nivou ukazuje na to da je Švajcarska veoma atraktivna lokacija za inostrana preduzeća sa aspekta plaćanja poreza. U prilog tome govori i činjenica da je kantonalnim poreskim zakonima data "domicilna privilegija“ za nerezidentne kompanije, čije se poslovne aktivnosti obavljaju izvan Švajcarske. Novim kompanijama se pružaju finansijske povlastice, koje obuhvataju vremenski period do 10 godina, i ta praksa je već dugo vremena kritikovana od strane Evropske unije. Očekuje se da bi upravo poreska reforma trebala da ukine ove beneficije.

\section{Razlike u poreskim stopama na dobit preduzeća između nivoa vlasti u Śvajcarskoj}

Ustavom Švajcarske (Federal Constitution of the Swiss Confederation) je definisano da pravo na propisivanje, uvođenje i naplatu poreza, između ostalog i poreza na dobit preduzeća, ne predstavlja ekskluzivno i isključivo pravo federacije. To pravo se ostvaruje i na nivou kantona što je posledica ustavom utvrđenih autonomnosti i suvereniteta kantona. Prema Ustavu, stav 1. i 2. člana 47. „Autonomija kantona" navodi se "da će Konfederacija 
Switzerland, investing in longterm or short-term deposits and performing other financial activities (Baumgartner \& Kunen, 2015).

- The tax rate at the federal level: The effective income tax at the federal level is $7.83 \%$ (nominal $8.5 \%$ ), with benefits realized on the basis of the deduction of interest on borrowed capital.

- The tax rate at the cantonal level is $1 \%-2 \%$ including a deduction in the form of deduced interest on borrowed capital.

Preferential tax regimes can create "tax havens" from certain countries and serve as tax incentives, or regimes that provide a different tax treatment of income achieved in the territory of domicile and of the revenues that are generated abroad ("ring-fencing"). Taking into account that the average rate of income tax for domicile corporations in 2015 amounted to $17.92 \%$, all companies that enjoy the privileged tax status pay lower taxes than the specified amount. As part of the tax reform that is being implemented in Switzerland, intensive work has been done to abolish the preferential regimes that the above listed enterprises enjoy.

When it comes to the off-shore financial centers, one could say with certainty that Switzerland with its preferential tax regimes certainly meets the requirements for being an off-shore center. At the same time, in order to attract foreign capital, it offers more favorable tax conditions for foreign companies, thus differentiating them from domestic corporations. According to some authors, each country that changes its tax laws and takes other measures through fiscal policy to attract foreign capital can be considered a tax haven jurisdiction (Todorović-Đurović \& Đorđevič, 2011). Most economists consider Switzerland as the first true tax haven. Back in 2015, Switzerland was declared the most attractive and most innovative country in the world, on a par with the United States.
Switzerland has no laws to control foreign companies so that the profits of these companies are not a subject to tax obligation (Bessard, 2008). A comparison made at the international level shows that Switzerland is an attractive location for foreign companies in terms of taxes. This is corroborated by the fact that the cantonal tax laws grant the "domicile privilege" to nonresident companies whose business activities are performed outside Switzerland. New companies are provided with financial benefits, including the time period up to 10 years, which is the practice criticized for a long time by the European Union. The tax administration reform is expected to abolish these benefits.

\section{Differences in Corporate Profit Tax Rates at Various Levels of Government in Switzerland}

The Swiss Constitution (The Federal Constitution of the Swiss Confederation) stipulates that the right to prescribe implementation and payment of taxes, including corporate profit tax, does not represent an exclusive right of the federation. This right shall be exercised at the cantonal level as a result of the constitutionally established autonomy and sovereignty of the cantons. According to the Constitution, paragraph 1 and 2 of Article 47 "Autonomy of a Canton" states "that the Confederation respects the autonomy of cantons," and that "the cantons will be left to perform the tasks and their autonomy in the implementation of these tasks will be respected" 
poštovati autonomiju kantona“, kao i to da "će kantonima biti prepušteno obavljanje zadataka uz poštovanje njihove autonomije pri realizaciji zadataka“" (The Federal Council, 2016).

Navedeno znači da svaki kanton, kao i opština imaju pravo da određuju visinu svoje poreske stope. Dvadeset šest kantona ima dvadeset šest različitih poreskih stopa. Kada se na to dodaju poreske stope 2.600 opština koliko trenutno postoji u Švajcarskoj, dobije se 2.626 različitih stopa, što ukazuje na kompleksnost sistema oporezivanja preduzeća i ujedno slobodu u definisanju poreske politike.

Nivo ukupne poreske obaveze zavisi od toga u kom kantonu je preduzeće locirano. Kantoni centralne $i$ istočne Švajcarske su veoma atraktivne teritorije sa poreskog aspekta. Najviše stope poreza su u 2016. godini zabeležene u zapadnim kantonima kao što su Geneva, Vaud, i Basel - Stadt (preko 22\% u 2016. godini), a najniže u centralnim i istočnim kantonima Lucerne, Obwalden i Nidwalden (oko 12\%). Poreske opterećenje se meri preko poreskih multiplikatora, odnosno indeksa koji se naziva Bak Taxation Index. BAK Indeks pokazuje poziciju kantona u smislu poreske konkurentnosti na međunarodnom nivou. Indeks je pokazatelj aktuelne poreske stope za kanton koji plaćaju preduzeća kao i nivoa poreskog opterećenja. Primenjuje se na iznos kantonalnog poreza. Prosečan indeks poreskog opterećenja zbirno na nivou svih kantona u Švajcarskoj iznosi 27,4\%. Pojedinačan pregled je dat na slici 1.

Porezi su opredeljujući faktor sa aspekta troškova koji utiče na lokaciju poslovanja preduzeća i donošenje odluka (KPMG Switzerland, 2016). Jedna multinacionalna kompanija koja želi da locira poslovanje u Švajcarskoj treba da sprovede kalkulaciju svoje ukupne poreske obaveze. Pod pretpostavkom da ista ostvaruje dobit od 80,000 CHF, vršiće izbor između:

- kantona koji ima najnižu poresku stopu od svih ostalih kantona (Lucern - 12,32\%) u kom je osnovni razlog niske poreske stope motivisanje stranih investicija $\mathrm{i}$ ulaganja $u$ ovo područje obzirom na njegovu nedovoljnu razvijenost i pretežno poljoprivredna delatnost. Ujedno Lucern odlikuje nizak poreski indeks;

- kantona sa visokom poreskom stopom na dobit (Zürich - 21,15\%) i visokim poreskim multiplikatorom ali vrlo urbanom i razvijenom sredinom sa mnogo većim mogućnostima za poslovanje i napredovanje.

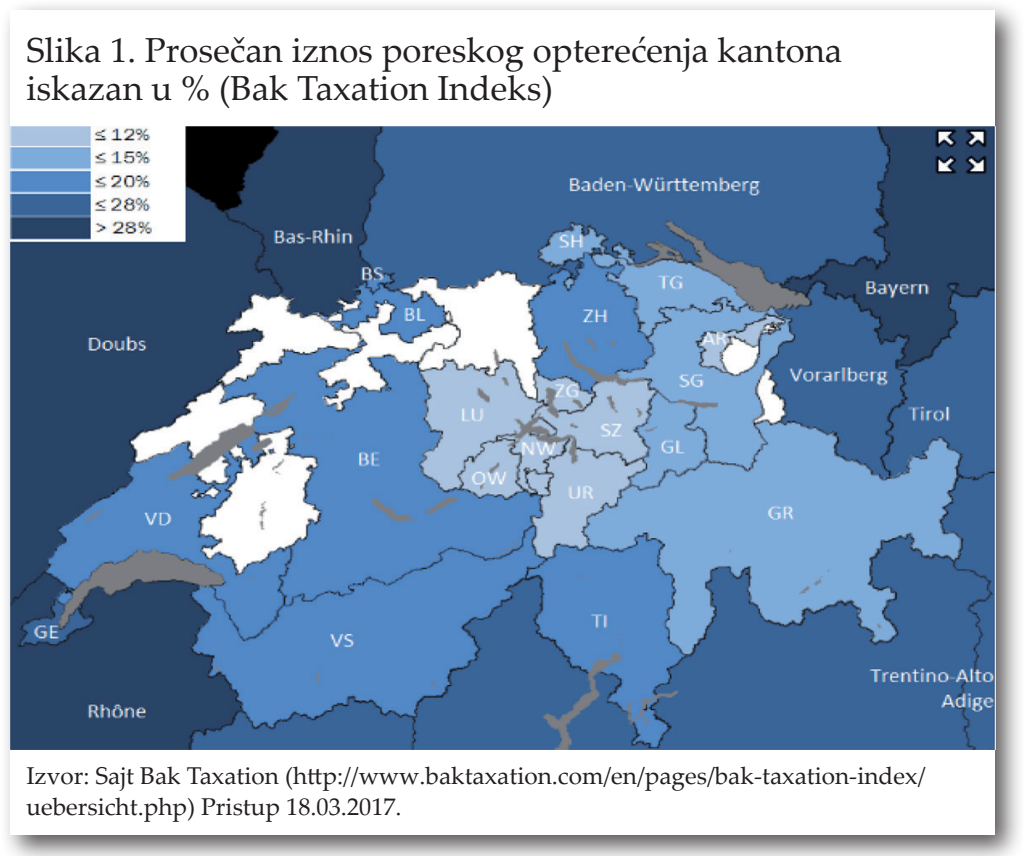


(The Federal Council, 2016).

This means that each canton and municipality have the right to determine the level of their tax rate. Twenty six cantons have twenty six different tax rates. When we add another 2,600 tax rates from the currently existing municipalities in Switzerland, we get 2,626 different rates, indicating the complexity of the system of business taxation and also the freedom in defining the tax policy.

The level of total tax liabilities depends on the canton in which the company is located. The cantons of the central and eastern Switzerland are very attractive territories in terms of tax. The highest tax rate in 2016 was recorded in the western cantons such as Geneva, Vaud and Basel - Stadt (over 22\% in 2016) and the lowest in the central and eastern cantons of Lucerne, Obwalden and Nidwalden (about 12\%). The tax burden is measured via the tax multiplier, and the so-called Bak Taxation Index. BAK index shows the position of the cantons in terms of tax competitiveness at the international level. The index is an indicator of the current tax rates for the specific canton paid by the companies, and the level of tax burden. It is applied to the amount of the cantonal tax. The average index of the collective tax burden at the level of all cantons in Switzerland amounted to $27.4 \%$. The breakdown is given in the figure 1 .

Taxes are a decisive factor in terms of costs, affecting the location of business operations and the decision-making process (KPMG Switzerland, 2016).

A multinational company that wants to locate its business in Switzerland should carry out the calculation of its total tax liability. Assuming that it achieved a profit of 80.000 $\mathrm{CHF}$, it would have the following choice:

- A canton which has the lowest tax rate of all other cantons (Lucerne - 12.32\%) in which the main reason for low tax rates is the stimulation of foreign investment and investment in this area considering its low level of development and predominant agricultural industry. Lucerne is also characterized by a low tax index;

- A canton with a high profit tax rate (Zürich - 21.15\%) and a high tax multiplier but very urban and developed areas with much larger business opportunities and advancement.

Figure 1. The average amount of the tax burden on cantons expressed in \% (Bak Taxation Index)

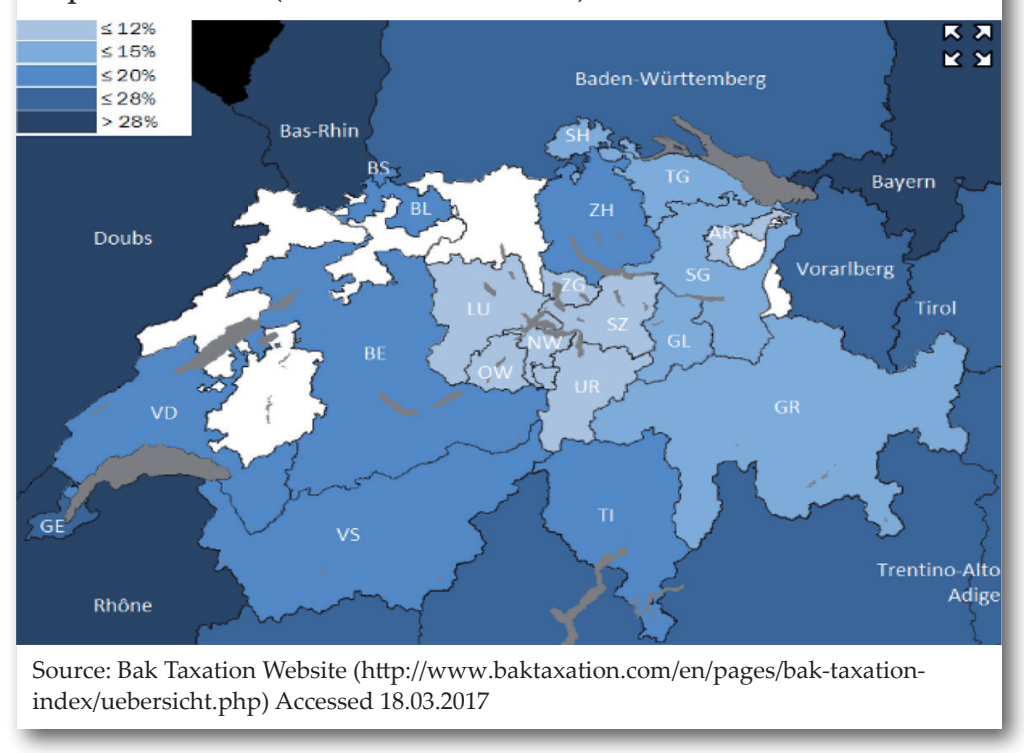


Tabela 1. Kalkulacija ukupne poreske obaveze na profit za kantone Zürich i Lucern

\begin{tabular}{|l|c|c|c|c|c|c|}
\hline Kantoni & Neto profit & $\begin{array}{c}\text { Poreska } \\
\text { stopa za } \\
\text { federaciju }\end{array}$ & $\begin{array}{c}\text { Poreska } \\
\text { stopa za } \\
\text { kanton }\end{array}$ & Multiplikator & $\begin{array}{c}\text { Porez na } \\
\text { profit za } \\
\text { kanton }\end{array}$ & $\begin{array}{c}\text { Ukupna poreska obaveza } \\
\text { na profit za kanton }\end{array}$ \\
\hline Zürich & $80.000 \mathrm{CHF}$ & $8,50 \%$ & $8,00 \%$ & $229 \%$ & $6.400 \mathrm{CHF}$ & $14.657 \mathrm{CHF}$ \\
\hline Lucern & $80.000 \mathrm{CHF}$ & $8,50 \%$ & $1,50 \%$ & $370 \%$ & $1.200 \mathrm{CHF}$ & $4.440 \mathrm{CHF}$ \\
\hline
\end{tabular}

Izvor: Baza podataka sa sajtova kantona Zürich (https://www.steueramt.zh.ch/internet/finanzdirektion/ksta/de/home.html), i kantona Luzern (http://www.luzern-business.ch/en/), Pristup 18.03.2017., autorovi proračuni ukupne poreske obaveze na profit za dva kantona.

Poreska stopa za kanton Zürich je 8\%, dok je za kanton Lucern 1,5\% i primenjuju se na iznos neto profita. Da bi se dobio konačan iznos poreske obaveze na nivou kantona koriste se poreski multiplikatori. Iznosi multiplikatora se razlikuju od kantona do kantona, ali i u okviru kantona (postoje opštine u kome je multiplikator veći u odnosu na drugu opštinu iz istog kantona). Multiplikator se sastoji iz kantonalnog, opštinskog i parohijskog udela. Kompanija je zainteresovana za lociranje u jednom od glavnih gradova u Švajcarskoj, te će se koristiti multiplikator koji važi za glavni grad ova dva kantona - u kantonu Lucern 370\%, u kantonu Zürich 229\%. Ipak to ne znači da je u Lucernu poresko opterećenje dobiti veće, iz razloga što je kantonalna poreska stopa za Zürich oko 5 puta veća od poreske stope na dobit u Lucernu. Način računanja ukupne poreske obaveze na nivou kantona je sledeći:

1. Osnovni kantonalni porez na profit se dobija tako što se poreska stopa na nivou kantona množi sa neto dobiti iz poslovanja preduzeća - za kanton Zürich $8 \%$ se množi sa $80,000 \mathrm{CHF}$, a za Lucern stopa od $1,5 \%$ sa 80,000 CHF;

2. Ukupna kantonalna poreska obaveza na profit se dobija tako što se dobijeni iznos osnovnog poreza na profit množi sa multiplikatorom i to za kanton Zürich 6,400 CHF se množi sa indeksom 229\%, a za Lucern 1,200 CHF sa indeksom 370\%.

Postoji još jedan način za računanje poreske obaveze, zvanično objavljen na sajtu BAK Taxation Indeks-a, po kome formula izgleda ovako (BAK Basel Economics AG, 2015):

$$
\mathrm{e}=(1-\mathrm{e}) * \mathrm{t}
$$

gde su: e - efektivna kombinovana poreska stopa na profit i t - nominalna kombinovana poreska stopa na profit $(8,5 \%$ x (najviša kantonalna poreska stopa x multiplikator za kanton))

Može se zaključiti da je poresko opterećenje preduzeća koji posluje na teritoriji kantona
Zürich za oko tri puta veće nego što bi to preduzeće bilo opterećeno kada bi poslovalo na teritoriji kantona Lucern. Upravo ova razlika u poreskom opterećenju između kantona je odraz njihove samostalnosti u određivanju poreskih stopa. Pojedini autori tumače samostalan „razvoj" poreskih stopa kao prisutnost poreske konkurencije. (Feld \& Reulier, 2009). Uspeh kantona se ogleda kroz iznos poreskih prihoda koji im pripada, tako da je u poređenju sa ostalim nivoima vlasti u Švajcarskoj - na prvom mestu su kantoni (46\%), potom federacija (38\%) i na kraju opštine (16\%) (Schmidheiny, 2006).

\section{Reforme poreza na dobit preduzeća (Corporate Tax Regime III) sa aspekta uticaja na poreski režim Švajcarske}

Decenijama unazad pa do danas, sve je više prisutna svest o postojanju poreskih sistema u kojima je poreska stopa nula, kao i poreski (troškovno) motivisanom seljenju kapitala iz jedne u drugu državu ili oblasti. Države koje posluju u skladu sa principom "no or low taxation" su naročito u centru zapažanja. Švajcarska je shodno tome, došla pod pritisak $\mathrm{u}$ pogledu postojanja privilegovanih poreskih režima na nivou kantona, kao i davanja "domicilnog“ tretmana inostranim preduzećima. Zbog toga je Svajcarski Savet usvojio nacrt zakona 05. juna 2015. godine i memorandum na tzv. Poresku reformu preduzeća III („,CTR III“). Ova poreska reforma predstavlja okosnicu prethodne dve poreske reforme sprovedene $\mathrm{u}$ Švajcarskoj i njihovu nadogradnju. Njen osnovni cilj je postepeno ukidanje privilegovanih poreskih režima, kao i uvođenje zamenskih, međunarodno prihvaćenih poreskih mera koje bi zadržale ili čak povisile stepen atraktivnosti Švajcarske kao poslovne lokacije za preduzeća.

Paket reformi predviđa osnovne i dodatne mere. Osnovne mere koje se uvode su $(\mathrm{PwC}$, 
Table 1. Calculation of the total tax liability on profits for the cantons of Zurich and Lucerne

\begin{tabular}{|l|c|c|c|c|c|c|}
\hline Cantons & Net Profit & $\begin{array}{c}\text { Federation } \\
\text { Tax Rate }\end{array}$ & $\begin{array}{c}\text { Cantonal } \\
\text { Tax Rate }\end{array}$ & Multiplier & $\begin{array}{c}\text { Cantonal } \\
\text { Tax on } \\
\text { Profit }\end{array}$ & $\begin{array}{c}\text { Total Cantonal Tax } \\
\text { Liability on Profit }\end{array}$ \\
\hline Zürich & $80,000 \mathrm{CHF}$ & $8.50 \%$ & $8.00 \%$ & $229 \%$ & $6.400 \mathrm{CHF}$ & $14.657 \mathrm{CHF}$ \\
\hline Lucern & $80,000 \mathrm{CHF}$ & $8.50 \%$ & $1.50 \%$ & $370 \%$ & $1.200 \mathrm{CHF}$ & $4.440 \mathrm{CHF}$ \\
\hline
\end{tabular}

Source: Database from the Websites of the canton of Zürich (https://www.steueramt.zh.ch/internet/finanzdirektion/ksta/de/home.html), and of the canton of Luzern (http://www.luzern-business.ch/en/), Accessed 18.03.2017, author's calculation of total tax liabilities on profit for two cantons.

The tax rate for the canton of Zurich is $8 \%$, while for the canton of Lucerne it is $1.5 \%$ and these rates are applied to the net income amount. To get the final amount of tax due at the cantonal level, the relevant tax multipliers are used. The multiplier amounts vary from one canton to another, but also within the cantons (some municipalities have a higher multiplier compared to other municipalities in the same canton). The multiplier consists of the cantonal, municipal and parish share. The company is interested in locating its business in one of the major cities in Switzerland and will use the multiplier that applies to the capital of these two cantons - the canton of Lucerne $370 \%$, and the canton of Zurich $229 \%$. However, this does not mean that the tax burden in Lucerne is larger, because the cantonal tax rate of Zurich is about 5 times higher than the profit tax rate in Lucerne. The method of calculating the total tax liabilities at the cantonal level is as follows:

1. The basic cantonal profit tax is obtained when the tax rate at the canton level multiplied by the net income from business operations - for the canton of Zurich 8\% is multiplied by $80.000 \mathrm{CHF}$, and for the canton of Lucerne $1.5 \%$ by $80.000 \mathrm{CHF}$;

2. The total cantonal profit tax liability is obtained by multiplying the amount of basic tax profit by the multiplier, in the canton of Zurich $6.400 \mathrm{CHF}$ is multiplied by the index of $229 \%$, and in Lucerne $1.200 \mathrm{CHF}$ multiplied by the index of $370 \%$.

There is another way to compute the tax liabilities, officially published on the website of the BAK Taxation Index, by using the following formula (BAK Basel Economics AG, 2015):

$$
\mathrm{e}=(1-\mathrm{e})^{*} \mathrm{t}
$$

where: e - effective combined tax rate on profit and $\mathrm{t}$ - nominal combined tax rate on profit $(8.5 \%$ * (the highest cantonal tax rate * multiplier for the canton)).
It can be concluded that the tax burden for businesses operating in the territory of the canton of Zurich is by about three times higher than it would have been when operating on the territory of the canton of Lucerne. This difference in tax burden between the cantons is a reflection of their autonomy in setting the tax rates. Some authors interpret independent "development" of tax rates as the presence of tax competition (Feld \& Reulier, 2009).

The success of the cantons is reflected through the amount of tax revenue that belongs to them, so when compared with other levels of government in Switzerland - the first place is taken by cantons (46\%), followed by the Federation (38\%) and by the municipalities (16\%) (Schmidheiny, 2006).

\section{Reform of the Corporate Profit Tax (Corporate Tax Regime III) and its Impact on the Tax Regime of Switzerland}

For decades now there has been an increasing awareness about the existence of the tax systems in which the tax rate is zero and about the tax (cost) motivated migration of capital from one country to another country or region. The states that operate in accordance with the principle of "no or low taxation" are particularly in the center of observations. Switzerland has, therefore, come under pressure as a result of its privileged tax regime at the cantonal level, as well as the "domicile" treatment of foreign companies. Therefore, the Swiss Council adopted a draft law on 05 June 2015 and a memorandum on the so-called "corporate tax reform III" ("CTR III"). This tax reform is the backbone of the previous two tax reforms implemented in Switzerland and their upgrade. Its primary goal is to phase out the privileged tax regimes and introduce the replacement tax 
professional service network, 2016):

1. Ukidanje privilegovanih poreskih režima;

2. Uvođenje OECD patentne kutije (patent box);

3. Uvođenje dodatnog smanjenja poreza za troškove za istraživanje i razvoj (R\&D);

4. Uvođenje tzv. „smanjenja nominalne kamate" (NID);

5. Ukidanje opštih olakšica na nivou kantona;

6. Smanjenje poreza na neto bogatstvo za međukompanijske pozajmice;

7. Prikazivanje skrivenih rezervi.

Kada je reč o privilegovanim poreskim režimima, teži se njihovom ukidanju ali i istovremenom uvođenju mera koje će biti isto tako atraktivne za domaća i strana preduzeća. Predviđen period tranzicije za ukidanje, odnosno prilagođavanje na izmenjene poreske uslove ovih kompanija je 5 godina. Povlašćeni poreski režimi vladaju na kantonalnom nivou, upravo zbog samostalnosti i slobode kantona da određuju sopstvene poreske stope. Obzirom da je startna pozicija preduzeća različita u zavisnosti od kantona $\mathrm{u}$ kom se lociraju, kantoni će morati da primene predviđene mere u sklopu poreske reforme, ali tako da te mere budu u skladu sa potrebama preduzeća. To znači da će i dalje postojati olakšice, samo će one biti ograničene, u smislu da će se olakšice koje se tiču patentne kutije kretati maksimalno do $90 \%$, dok će olakšice za R\&D biti do $150 \%$. Za NID olakšice će se kretati do 80\%.

U sklopu poreskih reformi, prezentovan je paket "poreske transparentnosti" (Tax Transparency Package). On se odnosi na uvođenje automatske razmene poreskih informacija i poreska pravila između zemalja članica OECD. Nacionalne vlasti zemalja članica OECD će biti u obavezi da na svaka 3 meseca šalju izveštaj ka svim drugim državama članicama o prekograničnim poreskim zakonima i aranžmanima transfernih cena. Automatska razmena informacija će omogućiti državama članicama da detektuju da li poreski zakon neke od zemalja ima uticaja na njih i postizanje veće pravičnosti u poreskoj konkurenciji (Europian Commision, 2015). Dostupnost poreskih podataka javnosti do sada je bila ograničena a stepen transparentnosti je bio nizak. Veliku ulogu u prikrivanju podataka imaju banke i bankarsko poslovanje čiji je zakonski princip poslovanja u zemljama poreskim rajevima povoljan poreski tretman i diskrecija. Mnoge države su uvele krivično kažnjavanje za lica koja povrede bankarsku poverljivost (Stojanović, 2010). Sve to dovodi do toga da u zemljama koje nude strožije uslove oporezivanja od ostalih zemalja dolazi do pojave erozije poreske osnovice i seljenja kapitala u druge zemlje sa nižim poreskim stopama na dobit (BEPS - Base erosion and profit shifting).

Od ostalih osnovnih poreskih mera, navešće se patent kutija koja podrazumeva oporezivanje prihoda od patenata i intelektualne svojine po nižoj poreskoj stopi. Takođe, jedna od mera je i smanjenje poreza na troškove povezane sa istraživanjem i razvojem, a pre svega na plate i zarade istraživača. Poreska reforma III uvodi koncept za prikazivanje latentnih rezervi $\mathrm{u}$ bilansu preduzeća, odnosno razlike između knjigovodstvene i fer vrednosti osnovnih sredstava - na federalnom, kantonalnom i opštinskom nivou. Kada se osnovna sredstva prenose iz neke države u Švajcarsku, latentne rezerve i novostvorena vrednost će biti vidljive u poreskom bilansu preduzeća. Isto tako, ako se skrivene rezerve ili novostvorena vrednost prenosi prilikom napuštanja Švajcarske u drugu zemlju, poreski obveznik je dužan da ih uračuna u konačnu poresku obavezu. Ovo se takođe odnosi i na transfere osnovnih sredstava iz inostranih ogranaka u Švajcarsku ili usled ukidanja federalnih poreskih režima.

Pored navedenih osnovnih mera, poreskom reformom III se još predviđaju i dodatne mere i to su poreska olakšanja za kantonalni porez na kapital, delimično oporezivanje kvalifikovanog prihoda od dividendi, i ostalo. Usklađivanje sa međunarodnim poreskim standardima i nivelacija poreza se predviđa za period između 2018. i 2020. godine.

Zbog velike raznolikosti između kantona, nije izvodljivo pronaći univerzalno rešenje koje bi bilo prihvatljivo za sve njih. Stoga, poreska reforma predviđa dva pravca uticaja (SwissAmerican Chamber of Commerce, 2016):

1. Primena novih međunarodnih zamenskih pravila ili

2. Smanjenje poreskih stopi na dobit na nivo međunarodno konkurentnih stopa uz finansijsku podršku od strane Vlade.

Smanjenje poreskih stopa na dobit preduzeća je planirano na kantonalnom nivou 
measures that are internationally accepted in order to maintain or even increase the level of attractiveness of Switzerland as a business location for companies.

The package of reforms provides the basic and additional measures. The basic measures that are being introduced are $(\mathrm{PwC}$, professional service network, 2016):

1. Suspension of the privileged tax regime;

2. Introduction of the OECD's patent box;

3. Introduction of an additional reduction of the research and development ( $R$ \& D) cost tax;

4. Introduction of the so-called "reduction in the nominal interest rate" (NID);

5. Abolition of the general benefits at the cantonal level;

6. 6Reduction of the tax on net wealth for intercompany loans;

7. Disclosure of hidden reserves.

When it comes to the privileged tax regimes, there is a tendency towards its abolition but also the simultaneous introduction of measures that will be just as attractive for domestic and foreign enterprises. There is a planned 5-year transitional period for these companies for the abolition of the regime or adaptation to the changing tax conditions. The preferential tax regimes exist at the cantonal level, because of the independence and freedom of the cantons to determine their own tax rates. Since companies have different starting positions depending on the canton in which they are located, the cantons will have to implement the measures foreseen in the framework of the tax reform, but in accordance with the needs of the relevant enterprises. This means that there will still be benefits, but limited, in the sense that the facilities concerning the patent box will reach the maximum of $90 \%$, while the R\&D facilities will increase up to $150 \%$. For NID the facilities will range up to $80 \%$.

As part of the tax reforms, the Tax Transparency Package has been presented. It refers to the introduction of an automatic exchange of tax information and tax policies between the OECD countries. National governments of the OECD member countries will be obliged to send a report every 3 months to all other member states on cross-border tax laws and transfer pricing arrangements. The automatic exchange of information would also create a level-playing field between EU companies in terms of transparency requirements and avoid legal complexities in terms of sector definition. (European Commision, 2015). The availability of tax information to the public has been limited so far and the level of transparency was low. A big role in hiding the data is played by the banks and banking operations whose legal principle in the tax haven countries is favorable tax treatment and discretion. Many countries have introduced criminal penalties for persons who breach the banking confidentiality (Stojanović, 2010). All this leads to the fact that in the countries offering stricter conditions than other countries this can lead to the erosion of the tax base and migration of capital to other countries with lower profit tax rates (BEPS - Base Erosion and Profit Shifting).

Anther basic tax measure that must be mentioned is the patent box, which includes the reduced taxation of income from patents and intellectual property. Also, one of the measures is reducing tax costs associated with research and development, especially in the wages and salaries of researchers. The Tax Reform III introduces the concept for revealing hidden reserves in the balance sheet of a company, i.e. the difference between the booking and fair value of fixed assets - at the federal, cantonal and municipal level. When an asset is transferred from a country to Switzerland, the latent reserves and added value will be reflected in the tax return of the company. Also, if hidden reserves or added value are transferred when leaving Switzerland, to another country, the taxpayer is obliged to calculate them as part of the final tax liabilities. This also applies to the transfers of fixed assets of foreign subsidiaries in Switzerland, or the transfers due to the abolition of the federal tax regime.

In addition to these basic measures, the Tax Reform III still envisages additional measures such as tax reliefs for cantonal tax on capital, partial taxation of qualified dividend income, etc. Compliance with international tax standards and tax leveling is projected for the period between 2018 and 2020 .

Because of the great diversity among the cantons, it is not possible to find a universal solution that would be acceptable to all of them. Therefore, the tax reform provides two lines of influence (Swiss-American Chamber of Commerce, 2016): 
nezavisno od sprovođenja poreskih mera u sklopu CTR III. Odluka o visini poreskih stopa na dobit preduzeća u ovom slučaju pripada isključivo kantonima. Tako su pojedini kantoni $\mathrm{u}$ međuvremenu snizili visinu poreskih stopa na dobit (kao što su Lucern, Zug i Schwyz), dok su neki samo najavili sniženje na procenat od $13 \%$ do $15 \%$ (Geneva), odnosno $13.79 \%$ (Vaud) ili 14\% (Zürich) u cilju zadržavanja svoje atraktivnosti. Jedan od razloga zašto su kantoni spremni na snižavanje poreskih stopa u sklopu reforme CTR III jeste to što se predviđa da će povećati ućešće kantona $u$ federalnom prihodu od poreza. To znači da će se sa sadašnjih $17 \%$ učešće povećati na $21,2 \%$ (Stevanović, 2016). U apsolutnim iznosima to je više za oko 1,1 biliona švajcarskih franaka (CHF). Cilj povećanja učešća jeste želja federacije da pruži finansijsku podršku kantonima u snižavanju poreskih stopa na dobit preduzeća.

\section{Posledice uvođenja reformi u porezu na dobit preduzeća}

Uvođenje poreskih reformi na dobit preduzeća u Švajcarskoj će imati najveći impakt na kantone. Kao što je rečeno, ova reforma će dovesti do toga da će povlašćeni režimi za holding, mešovite i domaće kompanije na nivou kantona nestati, dok će na federativnom nivou i dalje biti zastupljene principalne kompanije i finansijski ogranci samo uz uobičajene poreske režime. Zvaničan stav organa Evropske unije je da nesmetano funkcionisanje unutrašnjeg tržišta ne podrazumeva potpunu nivelaciju konkurentskih uslova, a najmanje poreskih uslova (Cvjetković, 2013). U Švajcarskoj se beleži trend pada poreskih stopa na dobit preduzeća. I u narednom periodu se očekuje nastavak opadajućeg trenda usled poreske reforme III.

Sledeća tabela pokazuje visinu federativnog i kantonalnog poreza na dobit onih preduzeća koja uživaju status preferencijalnih poreskih režima. Prikazane su trenutno važeće poreske stope na nivou federacije i kantona, kao i izmene u stopama nakon prelaska na uobičajen način oporezivanja, odnosno nakon primene mera poreske reforme. Većina preduzeća sa povlašćenim statusom će biti u obavezi da pređe na ordinaran način oporezivanja, što podrazumeva veće poreske stope na kantonalnom nivou. Povećanje je predviđeno u određenom procentu (opseg) što znači da će kantoni i dalje imati određeni stepen slobode da koriguju svoje stope $\mathrm{u}$ onim razmerama tako da to ne dovede do seljenja kapitala iz kantona ili uopšte iz države.

Tabela 2. Ukidanje preferencijalnih poreskih režima kao posledica CTR III

\begin{tabular}{|l|c|c|c|c|}
\hline & Holding kompanija & Mešovito preduzeće & $\begin{array}{c}\text { Principalno } \\
\text { preduzeće }\end{array}$ & Finansijski ogranak \\
\hline Nivo federacije & $7.83 \%$ & $7.83 \%$ & $7.83 \%$ & $7.83 \%$ \\
\hline Nivo kantona & $0.00 \%$ & $0.5-2.5 \%$ & $0.5-2.5 \%$ & $1-2 \%$ \\
\hline $\begin{array}{l}\text { Nivo kantona } \\
\text { (nakon CTR III) }\end{array}$ & $\begin{array}{c}\text { prelazak na } \\
\text { ordinaran način } \\
\text { oporezivanja 8-14\% }\end{array}$ & $\begin{array}{c}\text { prelazak na } \\
\text { ordinaran način } \\
\text { oporezivanja 8-14\% }\end{array}$ & $\begin{array}{c}\text { prelazak na } \\
\text { ordinaran način } \\
\text { oporezivanja 8-14\% }\end{array}$ & $\begin{array}{c}\text { prelazak na } \\
\text { ordinaran način } \\
\text { oporezivanja 8-14\% }\end{array}$ \\
\hline $\begin{array}{l}\text { Nivo federacije } \\
\text { (nakon CTRIII) }\end{array}$ & $\begin{array}{c}\text { primena izuzetaka } \\
\text { od oporezivanja i u } \\
\text { narednom periodu }\end{array}$ & $\begin{array}{c}\text { primena izuzetaka } \\
\text { od oporezivanja i u } \\
\text { narednom periodu }\end{array}$ & $\begin{array}{c}\text { prelazak na } \\
\text { ordinaran način } \\
\text { oporezivanja }\end{array}$ & $\begin{array}{c}\text { prelazak na } \\
\text { ordinaran način } \\
\text { oporezivanja }\end{array}$ \\
\hline
\end{tabular}

Izvor: Prikaz autora na osnovu podataka sa sajta Mondaq (http://www.mondaq.com/) Pristup 18.03.2017. 
1. Application of new international replacement rules;

2. Reducing the profit tax rates to the level of internationally competitive rates, with the financial support from the Government.

Reducing the tax rates on corporate profit is planned at the cantonal level, regardless of the implementation of tax measures within the CTR III. The decision about the amount of the tax rate on corporate profit in this case belongs exclusively to the cantons. Thus, in the meantime some cantons lowered the amount of profit tax rates (such as Lucerne, Zug and SZ), while some only announced the reduction of the rates to $13 \%-15 \%$ (Geneva), $13.79 \%$ (Vaud) or $14 \%$ (Zürich) in order to maintain their attractiveness. One of the reasons why the cantons are willing to lower their rates as part of the CTR III is the fact that their participation in the federal tax revenues is expected to be increased. This means that their share will increase from the current $17 \%$ to 21.2\% (Stevanović, 2016). In absolute amounts, this is by about 1.1 billion Swiss francs (CHF) more than today. The goal of increasing the participation reflects the Federation's desire to provide financial support to the cantons in lowering the tax rates on corporate profit.

\section{Consequences of the Introduced Reforms in the Corporate Profit Tax}

The introduction of tax reforms on corporate profit in Switzerland will have the greatest impact on the cantons. As stated, this reform will lead to the abolition of preferential regimes for holding, mixed and domestic companies at the cantonal level, while at the federal level principal companies and financial branches will continue to be represented alongside the common tax regimes. The official opinion of the European Union is that the smooth functioning of the internal market does not imply the complete leveling of the competitive conditions, the least of all when it comes to tax requirements (Cvjetković, 2013). Switzerland has recorded a downward trend in the corporate profit tax rates. And in the coming period this downward trend is expected to continue due to the tax reform III.

The following table shows the level of the federal and cantonal profit tax of those companies which enjoy the status of preferential tax regimes. It shows the currently applicable tax rates at the federal and cantonal level, as well as the changes in rates after switching to the normal mode of taxation, i.e. after the implementation of the tax reform measures. Most companies with the privileged status will be required to move to the ordinary way of taxation, which means higher tax rates at the cantonal level. The increase is anticipated in a certain percentage (range) which means that the cantons will continue to have a certain degree of freedom to adjust their rates to a certain degree so that this does not lead to a migration of capital from the specific canton or even from the country.

Table 2. Repeal of the preferential tax regime as a result of CTR III

\begin{tabular}{|l|c|c|c|c|}
\hline & Holding company & Mixed company & Parent company & $\begin{array}{c}\text { Finance company/ } \\
\text { branch }\end{array}$ \\
\hline Federation level & $7.83 \%$ & $7.83 \%$ & $7.83 \%$ & $7.83 \%$ \\
\hline Cantonal level & $0 \%$ & $0.5 \%-2.5 \%$ & $0.5 \%-2.5 \%$ & $1 \%-2 \%$ \\
\hline $\begin{array}{l}\text { Federation level } \\
\text { (after CTRIII) }\end{array}$ & $\begin{array}{c}\text { application of tax } \\
\text { exemptions in the } \\
\text { following period }\end{array}$ & $\begin{array}{c}\text { application of tax } \\
\text { exemptions in the } \\
\text { following period }\end{array}$ & $\begin{array}{c}\text { transition to an } \\
\text { ordinary way of } \\
\text { taxation } \\
8 \%-14 \%\end{array}$ & $\begin{array}{c}\text { transition to an } \\
\text { ordinary way of } \\
\text { taxation } \\
8 \%-14 \%\end{array}$ \\
\hline $\begin{array}{l}\text { Cantonal level } \\
\text { (after CTRIII) }\end{array}$ & $\begin{array}{c}\text { transition to an } \\
\text { ordinary way of } \\
\text { taxation } \\
8 \%-14 \%\end{array}$ & $\begin{array}{c}\text { transition to an } \\
\text { ordinary way of } \\
\text { taxation } \\
8 \%-14 \%\end{array}$ & $\begin{array}{c}\text { transition to an } \\
\text { ordinary way of } \\
\text { taxation } \\
8 \%-14 \%\end{array}$ & $\begin{array}{c}\text { transition to an } \\
\text { ordinary way of } \\
\text { taxation } \\
8 \%-14 \%\end{array}$ \\
\hline
\end{tabular}

Source: The overview prepared by the author, database from Mondaq Website (http://www.mondaq.com/) Accessed 18.03.2017 
Zbog uvođenja poreskih reformi $u$ onim kantonima u kojima su veoma zastupljene korporacije sa privilegovanim statusom kao i visoke poreske stope na profit, korporacije će morati da plate dodatan iznos poreza nakon što se pređe na ordinaran način oporezivanja. Da bi se opterećenje ublažilo, potrebno je da se primene određena poreska umanjenja ili odbitak. Oni kantoni koji imaju visoke stope na profit ali u kojima nisu toliko zastupljene privilegovane korporacije, uz određene poreske olakšice sve korporacije koje su podvrgnute ordinarnom oporezivanju će profitirati. Iz tog razloga, u kantonima koji su do sada bili fiskalno nepovoljni za korporacije, otvoriće se prostor za povoljnija ulaganja i uopšteno za povećanje pokazatelja kvaliteta lokacije. Sa druge strane, posledice poreskih reformi za one kantone $\mathrm{u}$ kojima su ordinarne poreske stope na dobit inače na niskom nivou mogu da uz male korekcije zadrže njihovu atraktivnost (pr. Lucern). Da bi umanjile deficit, kantoni će morati da se okrenu traženju specijalnih poreskih rešenja, nezavisno od toga što bi povećale učešće u poreskom prihodu federacije.

Na osnovu navedenog može se zaključiti da će poreska reforma III izazvati velike finansijske troškove za federaciju. Na nivou federacije će se osetiti pad poreskih prihoda za oko 1,3 biliona CHF. Najveći deo prihoda će otići na pomenutu finansijsku podršku kantonima u smanjenju njihove poreske stope na dobit preduzeća. Kako se prihod Švajcarske uglavnom zasniva na fiskalno atraktivnim poslovnim lokacijama, vrlo je bitno ove iznose rashoda finansirati iz budžeta. Pa je tako budžetom za 2017. godinu do 2019. godine obuhvaćena poreska reforma III. Na nivou kantona je drugačija situacija nego što je to na federativnom nivou. Sve dok se za privilegovane korporacije budu primenjivale zamenske mere, reforma neće izazvati poreski deficit. Pad prihoda se jedino može očekivati u slučajevima kada su korporacije bile podvrgnute ordinarnom oporezivanju dobiti sada prešle sa novim zamenskim merama na povoljniji sistem oporezivanja. To smanjenje prihoda se očekuje u iznosu od oko 2 biliona CHF.

Navedene mere kao što su transparentnost informacija i sprečavanje zloupotrebe prava od strane multinacionalnih kompanija predstavljaju pomoćne mere za ostvarivanje osnovnog cilja Evropske unije a to je uvođenje zajedničke konsolidovane korporativne poreske osnovice (CCCTB). Zajednička poreska osnovica predstavlja skup poreskih pravila $\mathrm{u}$ vezi sa korporacijama $\mathrm{u}$ pogledu obavljanja njihovih poslovnih aktivnosti na teritoriji Evropske unije. Kao takva ona je najdelotvornije sredstvo za otklanjanje privilegovanih poreskih režima i sprečavanje narušavanja poreske konkurencije. Iako je osnovna svrha zajedničke poreske osnovice stvaranje efikasnog modela oporezivanja EU kompanija, ipak postoje negativni stavovi i opiranja od strane država članica koje smatraju da bi se na taj način odrekle dela svog poreskog suvereniteta i ostale bez značajnog dela poreskih prihoda. Ova reakcija ne čudi, a naročito od strane Švajcarske, koja je zemlja sa natprosečnim pokazateljima, kako u pogledu zaposlenosti, javnih prihoda, obrazovanja, institucija, ekonomskih rezultata poslovanja, i ostalog. Samo zahvaljujući privilegovanim poreskim režimima $i \mathrm{i}$ "domicilnom tretmanu“ stranih kompanija, Švajcarska je danas veoma atraktivna zemlja i obezbeđuje visoke poreske prihode. Procenjeno je da se od takvih kompanija godišnje naplati 5,3 biliona CHF poreskih prihoda (Swiss-American Chamber of Commerce, 2016). Multinacionalne kompanije, bilo da se radi o ograncima domaćih ili stranih kompanija, ostvaruju veliki uticaj na Švajcarsku ekonomiju i prihode od poreza. Iako čine 7\% od ukupnog broja kompanija u Švajcarskoj, one obezbeđuju više od polovine poreskih prihoda.

Ostaje da se vidi da li će poreske reforme zaista biti sprovedene u Švajcarskoj i ako budu sprovedene, da li će se iste odraziti negativno na atraktivnost ove teritorije. Sudeći po glasanju na referendumu o poreskim reformama održanom februara 2017. godine, sprovođenje mera će biti odloženo do daljnjeg. Kao posledica reformi došlo bi do seljenja kapitala i kompanija iz Švajcarske, što bi se negativno odrazilo kako na prihode od poreza, ali isto tako i na građane koji su zaposleni $\mathrm{u}$ tim multinacionalnim kompanijama (oko 8 miliona građana). Da bi ostala atraktivna, plan je podrazumevao dalje snižavanje poreskih stopa od strane kantona što bi vrlo verovatno dovelo do povećanja poreskog opterećenja samih građana. Nezavisno od toga, kantoni će nastaviti da smanjuju poreske stope. 
Due to the introduction of tax reforms in the cantons with numerous corporations having the privileged status and high tax rates on profits, the corporations will have to pay an additional amount of taxes after switching to the ordinary way of taxation. In order to alleviate the tax burden, it is necessary to apply certain tax reductions or deductions. In the cantons with high profit rates but not so many privileged corporations, all corporations that are subject to the ordinary taxation with certain tax benefits will profit. For this reason, the cantons which have so far been fiscally unfavorable to corporations will be given room for more favorable investment and generally for enhancing the quality indicators of their location. On the other hand, the consequences of tax reforms for the cantons with ordinary income tax rates typically at a low level can retain their attractiveness with minor adjustments (e.g. Lucerne). To reduce the deficit, the cantons will have to find special tax solutions, regardless of the increased participation in the federation's tax revenue.

Based on the above mentioned, it can be concluded that the tax reform III causes major financial costs for the federation. At the federal level the country will experience declines in tax revenues by about 1.3 billion Swiss francs. The largest part of the revenue will go to the mentioned financial support for the cantons in reducing their tax rates on corporate profit. Considering the fact that revenues in Switzerland are mainly based on fiscally attractive business locations, it is essential for the country to finance expenditures from the budget money. The budget for 2017 up to 2019 includes all charges that will come from the tax reform III. The situation at the cantonal level is different than at the federal level. As long as the privileged corporations are applying replacement measures, the reform will not cause a tax deficit. The fall in the country's revenues can only be expected in the cases where corporations that were subject to the ordinary tax profit are now transferred by means of replacement measures to the more favorable taxation system. This reduction in revenues is expected to amount to 2 billion CHF.

The measures such as transparency of information and prevention of the abuse of rights by the multinationals represent assistance measures for achieving the primary objective of the European Union and for introducing the common consolidated corporate tax base (CCCTB). A common tax base is a set of tax rules relating to corporations in terms of their business performance on the territory of the European Union. As such, it is the most effective tool in the elimination of the privileged tax regimes and in the prevention of distortions of tax competition. Although the main purpose of a common tax base is the creation of an effective model of the EU company taxation, there are negative attitudes and reluctance by the member states which consider it as giving up a part of their tax sovereignty and getting left without a significant part of the tax revenues. This reaction is not surprising, especially on the part of Switzerland, which is the country with above-average indicators in terms of employment, public revenues, education, institutions, economic and business results, etc. It is only thanks to the privileged tax regimes and "domicile treatment" of foreign companies that Switzerland is today a very attractive country with high tax revenues. According to the estimates, Switzerland annually collects 5.3 billion $\mathrm{CHF}$ in tax revenues from such companies (Swiss-American Chamber of Commerce, 2016). Multinational companies, whether they are domestic or branches of foreign companies, have a tremendous impact on the Swiss economy and tax revenues. Although they account for $7 \%$ of the total number of companies in Switzerland, they provide more than half of the tax revenues.

It remains to be seen whether the tax reform is actually going to be implemented in Switzerland and if it does get implemented, will it exert a negative effect on the attractiveness of this territory. Judging by the votes in the referendum on tax reforms, held in February 2017, the implementation of the measures will be postponed until further notice. One of the results of the reforms would be the migration of capital and companies from Switzerland, which could have a negative impact on the profit tax, but also on the citizens who are employed in these multinational companies (about 8 million people). In order to remain attractive, Switzerland considered a further reduction of tax rates by the cantons which would very likely increase the tax burden on the citizens. 
Na grafiku je prikazana dinamika kretanja poreskih stopa na dobit preduzeća u periodu od deset godina (od 2006. do 2015. godine) iskazanih u procentima za sva tri nivoa vlasti. Prikazane stope su manje zbog činjenice da sve do 2014. godine, devet od dvadeset šest kantona nije objavljivalo svoje poreske stope.

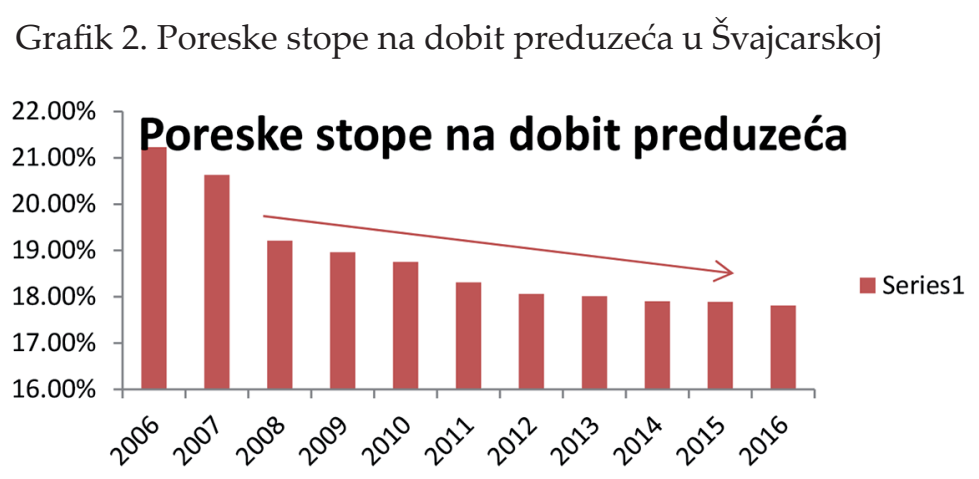

Izvor: Sajt KPMG Switzerland (https://home.kpmg.com/ch/en/home.html) Pristup 18.03.2017.

\section{Zaključak}

Reforma Švajcarskog poreskog sistema korporacija se javila kao neophodan uslov usled promena u međunarodnom poreskom sistemu i manipulacija u oporezivanju dobiti korporacija na teritoriji Evropske unije. To je dovelo do odobravanja i preduzimanja paketa poreskih mera čiji je osnovni cilj bio usaglašavanje sa poreskim standardima uz zadržavanje atraktivnosti zemlje za različite poslovne aktivnosti i korporacije. CTR III ima za cilj da eliminiše trenutne nestabilnosti u poslovanju, omogućavajući dugoročno i stabilno poresko planiranje.

Poreska reforma korporacija III će imati uticaj na državni poreski sistem, najranije od 2019. godine. Reforma će se najviše odraziti na kantone zbog čega je većina njih već odlučila da snizi svoje poreske stope na dobit, a mnoge će to učiniti u narednom periodu. Svaki kanton će dizajnirati stope u skladu sa specifičnim okolnostima i zahtevima koji su karakteristični za kanton. Promene u stopama će se odraziti na njihovu atraktivnost, tako da će neki kantoni sa poslednjeg mesta preći da budu među prvima u pogledu povoljnih uslova za poslovanje. Tako na primer, glasači u katnonu Vaud su izglasali da se poreska stopa korporacija snizi sa $22 \%$ na $13,79 \%$, čime će ovaj kanton preći sa 24 . mesta na 5. mesto prema kvalitetu lokacije. Promene će dovesti do rasta među-kantonalne konkurentnosti. Evropska unija ovo posmatra kao zdravu pojavu, jer je u interesu država članica da se stane na put nezakonitoj poreskoj konkurenciji. U isto vreme mala i srednja preduzeća će najviše profitirati od uvedenih zamenskih mera koje će pozitivno uticati na njihove uslove poslovanja.

Dosadašnja rezerva koja je postojala na OECD Model konvenciju koja se bavi pitanjem razmene informacija između država ugovornica, je skinuta na taj način što je Švajcarska potpisala sporazum po kome je ipak pristala na ustupanje svih traženih poreskih informacija, što je takođe bilo zahtevano aktuelnom reformom. Kao što je rečeno, Švajcarska će uvesti niz zamenskih mera kako bi nadomestila nedostatke od uvođenja međunarodnih poreskih standarda, i time zadržala povlašćene uslove poslovanja u odnosu na ostatak Evrope, pa i sveta. Na taj način učiniće sve kako bi ona i dalje bila najbolja opcija za multinacionalne korporacije. Zbog toga su pojedine države članice Evropske unije izrazile bojaznost da će nove zamenske mere Švajcarske biti ponovo štetne za okolne zemlje i članice.

Ipak ostaje određena doza rezerve $u$ pogledu početka primene mera obzirom da je na referendumu postignuta ubedljiva većina za zadržavanje dosadašnjeg režima oporezivanja preduzeća. 
Nevertheless, the cantons will continue to reduce the tax rates. The chart below depicts the dynamics of the tax rates on corporate profit in the period of ten years (2006 - 2015) expressed as a percentage at all three levels of government. The shown rates are lower due to the fact that until 2014, nine of the twenty-six cantons did not publish their tax rates. that some cantons will come to the first place in terms of favorable business conditions. For example, the voters in canton Vaud voted to lower the corporation tax rate from $22 \%$ to $13.79 \%$, which will move the canton from its $24^{\text {th }}$ place to the $5^{\text {th }}$ place according to the quality of the location. The changes will lead to an increase in inter-cantonal competition.

\section{Chart 2. Tax rates on corporate profit in Switzerland}

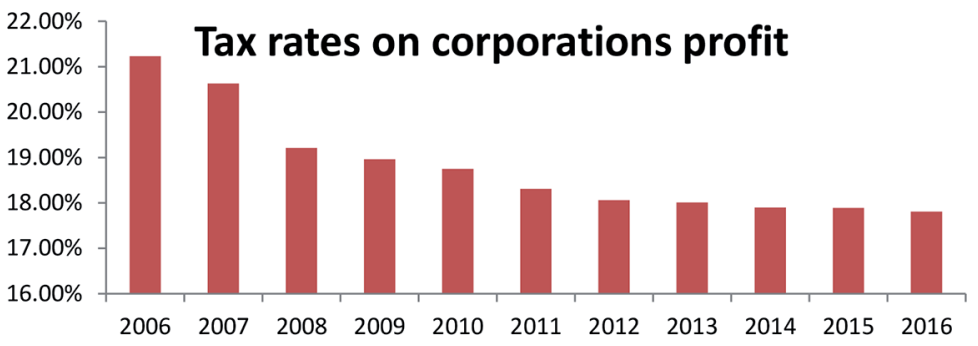

Source: KPMG Switzerland Website (https://home.kpmg.com/ch/en/home.html) Accessed 18.03.2017

\section{Conclusion}

The reform of the Swiss corporate tax system emerged as a necessary condition due to the changes in the international tax system and manipulation in the corporate profit taxation in the European Union. This led to the approval and undertaking of a package of tax measures whose main objective was to comply with the tax standards while maintaining the country's attractiveness for a variety of business activities and corporations. CTR III aims to eliminate the current instability in the business environment, enabling the long-term and stable tax planning.

The Corporation Tax Reform III will have an impact on the national tax system, at the earliest from 2019. The reform is predominantly going to affect the cantons, which is why most of them have already decided to lower their tax rates on income, and many will do so in the future. Each canton will define its rates in accordance with the specific circumstances and the requirements which are typical for that canton. The changes in the rates will affect their attractiveness, so
The European Union looks at this as a healthy phenomenon because it is in the interest of the member states to put an end to the illegal tax competition. At the same time, small and medium enterprises will benefit most from the introduced replacement measures that will have a positive impact on their business conditions.

The reserve that existed concerning the OECD Model Convention, which deals with the issue of information exchange between the Contracting States, was taken off after Switzerland signed an agreement by which it consented to the assignment of all required tax information, which is also requested by the current reform. As has been said, Switzerland will introduce a number of replacement measures to offset the disadvantages of introducing the international tax standards, and thus retain the preferential business conditions in relation to the rest of Europe and the world. In this way, Switzerland will do everything to remain the best option for multinational corporations. Therefore, the individual EU member states have expressed concern that the new replacement rates will again be detrimental to the surrounding countries and the member states.

Still, a certain dose of reserve remains when it comes to the beginning of the implementation of these measures since the referendum results showed a convincing majority in favor of retaining the current tax regime for corporations. 


\section{Literatura / References}

1. Radičić A, M., Raičević, B. 2008. Javne finansije. Beograd: DATA STATUS.

2. Todorović-Đurović, J., Đorđević, M. 2011. Direktni porezi. Niš: Ekonomski fakultet Univerziteta u Nišu.

3. Stojanović, S. 2010. Nepravična poreska konkurencija u Evropskoj Uniji. Kragujevac: Pravni fakultet Univerziteta u Kragujevcu.

4. Cvjetković, C. 2013. Mere protiv štetne poreske konkurencije u Evropskoj uniji. Zbornik radova Pravnog fakulteta u Novom Sadu, Vol. 47 No. 3. Pp. 413-427.

5. Schmidheiny, Kurt. 2006. Income segregation and local progressive. Journal of Public Economies, Vol 90 No. 3. Pp 429-458.

6. Feld, Lars P., \& Reulier, E. 2009. Strategic tax competition in Switzerland: Evidence from a panel of the Swiss cantons. German Economic Review Vol. 10 No. 1. Pp 91-114.

7. Bessard, P. 2008. Tax competition: the Swiss case. Liberal institute, Pp. 85-104.

8. Stevanović, N. 2016. Swiss Corporate Tax Reform III-The Swiss Parliament approves the Tax Reform in the Corporate Sector. (http://www.mandaris.com/en/assets/File/ Newsletter\%20July\%202016\%20Swiss\%20 Corporate $\% 20$ tax $\% 20$ reform $\% 20 I I I . p d f$, 17.03.2017.)
9. Baumgartner, B., Kunen, J-W. 2015. The Swiss Investment Climate: Main tax features. Loyens \& Loeff. (http://cdn.loyensloeff.com/ media/3978/investment_climate_swiss.pdf, 17.03.2017.)

10. Kurtin, O. 2013. A Swiss Principal Model Case Study: Restructuring a multinational corporation to achieve territorial optimization. (http://www.swissprincipal. com/wp-content/uploads/2013/07/ KurtinLaw-SwissPrincipalModel.pdf, 18.03.2017.)

11. Swiss-American Chamber of Commerce. November 2016. Corporate Tax Reform III: Facts \& Figures. (http://www.amcham.ch/ news/downloads/161124_Corporate_Tax_ Reform_III_Facts\&Figures.pdf, 17.03.2017.)

12. European Commision. 2015. Council Directive amending Directive 2011/16/EU as regards mandatory automatic exchange of in the field of taxation. (http://ec.europa. eu/taxation_customs/sites/taxation/files/ resources/documents/taxation/company_ tax/transparency/com_2015_135_en.pdf, 17.03.2017.) 
13. PwC professional service network. 2016. Switzerland passes final corporate tax reform package to enhance global competitivnes. (https://www.pwc.com/us/ en/tax-services/publications/insights/assets/ pwc-switzerland-passes-final-corporate-taxreform-package.pdf, 17.03.2017.)

14. KPMG Switzerland. 2016. Clarity on Swiss Taxes. (https://assets.kpmg.com/content/ $\mathrm{dam} / \mathrm{kpmg} / \mathrm{pdf} / 2016 / 05 /$ ch-clarity-on-swisstaxes-2016-en.pdf, 17.03.2017.)

15. KPMG Switzerland. 2014. Taxation of Cross-Border Mergers and Acquisitions. (https://home.kpmg.com/content/dam/ kpmg/pdf/2014/05/switzerland-2014.pdf, 17.03.2017.)
16. Delloite. 2015. Taxation and Investment in Switzerland 2015. (https://www2. deloitte.com/content/dam/Deloitte/ global/Documents/Tax/d t t l - taxswitzerlandguide-2015.pdf, 17.03.2017.)

17. BAK Basel Economics AG. 2015. BAK Taxation Index 2015 Tax Parameters. (http://www.baktaxation.com/en/pages/ zuerich/corporations/tax-parameters.php, 17.03.2017.)

18. The Federal Council. 2016. Federal constitution of the Swiss Confederation. (https://www.admin.ch/opc/en/classified-co mpilation/19995395/201601010000/101.pdf, 17.03.2017.) 